\title{
Ka'b Al-Ahbar: Founder of the Transformation Jewish Tradition to Islam
}

\author{
Khoirul Anwar ${ }^{1}$, Abu Hapsin' ${ }^{2}$ Nazar Nurdinn ${ }^{3}$, Ubbadul Adzkiya ${ }^{4}$, \\ Iman Fadhilah ${ }^{5}$, Tedi Kholiludin ${ }^{6}$ \\ Lembaga Studi Sosial dan Agama Semarang ${ }^{1}$ \\ Universitas Islam Negeri Walisongo Semarang ${ }^{2,3}$ \\ Universitas Wahid Hasyim, Semarang, Indonesia ${ }^{4,5,6}$
}

\{khoirulanwar_88@yahoo.co.id ${ }^{1}$, ahafsin@gmail.com², nazar@walisongo.ac.id ${ }^{3}$ \}

\begin{abstract}
The purpose of writing this paper is to conduct an in-depth exploration of the role of Ka'b Al-Ahbar in exporting the Jewish tradition to Islam. This study found Ka'b's role in the transformation of Jews to Islam was very striking compared to other figures such as Abdullah bin Salam and Wahb bin Munabbih. Ka'b showed his capacity as a dignified Islamic intellectual because in addition to being a reference for asking the Sabahat about Jewish religious traditions, it was also permissible to share stories of previous religions with Muslims. This transformation of the story of the Jews in Islam (isra'iliyyat) was successful because the explanation of the Koran about the previous people was very brief. This fact refutes the opinion of scholars who call him a critic of Islam.
\end{abstract}

Keywords: Ka'b Al-Ahbar; Israilliyyat; Jewish Tradition; Islam

\section{Introduction}

In Islamic literature, the biography of the Prophet Muhammad can be found from stories that come from the Israelites or the Jews. These studies are called isra'iliyyat or stories that come from Jewish, Christian or other religious sources [1, pp. 13-14]. The name isra'iliyyat refers more to the son of Ya'qub bin Ishaq (Nation of Israel) because Jewish sources are more dominant. This paper will specifically discuss the Jewish tradition of the diaspora, not the story of isra'iliyyat which has a general meaning [2, p. 45]. Figures who developed the Jewish tradition to Islam include Ka'b al-Ahbar, Abdullah bin Salam and Wahb bin Munabbih. They are Jewish intellectuals who converted to Islam after the Prophet Muhammad died. Armed with previous religious knowledge, they explain the verses in the Koran which are relatively concise telling stories about previous religions. The Jewish tradition is limited to the story told by Ka'b Al-Ahbar. This figure is studied because his name is often mentioned in classical Islamic literature, as the first agent to transform the Jewish tradition to Islam.

Ka'b Al-Ahbar is not actually his real name. The name Ka'b is not listed in early Islamic historical literature as written by Muslim historians Ibn Sa'd and at-Tabari [3, Op. 24]. The name Ka'b was used by Arabic Jews to pronounce Ya'qub in Hebrew. However, this opinion was challenged because generally the Hebrew term in the Qur'an did not change [3, Opp. 1719], [4, Opp. 24-63], [5, Opp. 32-33]. Islamic historians agree that Ka'b has the name Abu 
Ishaq and comes from the Yemeni tribe of Himyar. While the name of his ancestor is still being debated [6, p. 151]. The name Ka'b is a male name. The name Ka'b is commonly used in Arab society to refer to men like Ka'b bin Kilab and Ka'b bin Rabi'ah [7, Op. 720]. While the word Al-Ahbar is used to distinguish the name Ka'b from other names. The word Al-Ahbar comes from the Hebrew word 'al-Habr' to refer to all those who belong to a group of Persian Jews. In the Arab region, al-Habr was originally used to refer to smart Jews. During its development, the name was used to refer to all intellectuals regardless of their religious background [3, Opp. 22-23]. The name Ka'b relies on the word al-Ahbar or al-Hibr because it has a lot of knowledge [8, Op. 154], or the knowledge that Ka'b had was part of the knowledge inherited by the Jewish priests [9, Op. 98].

All historians, starting from Ibn Sa'd, At-Tabari, Ibn Hibban, Al-Asbihani, an-Nawawi, asSuyuti agree that Ka'b al-Ahbar was born and raised in Yemen, namely in Himyar [10, Op. 309] [11, Op. 627] [12, Op. 334] [13, Op. 905] [14, Op. 69] [15, Op. 24]. Ka'b died in Hims, Sham in $32 \mathrm{H}$ during the caliphate of Usman bin 'Affan. Ka'b was born around $575 \mathrm{AD}$ or 72 years before Hijriah. Ka'b lived to the age of 104 years [12, Op. 24]. However, the age of 104 is doubtful. In old age, a person may not be able to travel very far with a physical condition that is healthy, strong and in good shape [3, Op. 30]. Ka'b himself had visited Medina during the reign of Umar bin al-Khattab, then to Sham twice and had the pilgrimage to Mecca once. $\mathrm{Ka}$ 'b is believed to be not less than 80 years old. Meanwhile, the birthplace of Ka'b in Yemen is an area where Judaism is the official religion.

The focus of the study on Ka'b Al-Ahbar makes this study different from previous studies. Therefore, the data collection process was carried out by studying literature, while the data analysis was carried out using the interpretive socio-historical method.

\section{Discussion}

\subsection{Ka'b and Conflict in Yemen}

Ka'b was born and raised in Yemen. According to historians, Jews developed in Yemen under the rule of Tubban Abu Karb As'ad Kamil in 385-420 AD After conquering Persia, Tubban converted to Judaism because of the influence of Jewish intellectuals from Bani Quraizah who lived in Yasrib [16, Opp. 35-49], [17, Opp. 537-542]. The influence of Jewish intellectuals then made Yemen under Tubban rule begin to eliminate paganism [17, Opp. 537538], [18, Opp. 74-75].

The development of Judaism in Yemen stems from the meeting of residents with trading groups in Syria, both by land and by sea. This is evidenced starting from the story of Prophet Solomon and the Kingdom of Saba' and then continued by the Jews who traveled to Yemen via the Hijaz. The migration of Jews was based on economic factors, flight from war or other factors [17, Op. 538], [19, Opp. 16-22]. Religion in Yemen is not only Jewish, but paganism, Christianity, Abrahamic religion and Magi. The majority of the population of Yemen follows Jews and Christians [18, Opp. 75-77], [20, Opp. 18-20]. The spread of Christianity to Yemen was carried out by King Constantius since 356 AD, then built a place of worship in the 'Adn region and two places of worship in Himyar.

Meanwhile, Jews in Yemen developed through the Himyar Kingdom. The ruler of Himyar, $\mathrm{Zu}$ Nuwas tried hard to prevent his area from spreading Christianity because it could threaten his power. The Christian population living in Yemen is not considered as its people, but under the protection of the Abbisian Christian Rulers, and carrying out attacks against followers of 
the Christian religion. This story in the Koran is mentioned in the Surah Al-Buruj [85]: 4-8 [21, pp. 93-94]. The Christian Abbisinians then responded to the actions of the Himyar rulers by conquering the territory [18, pp. 76-77]. This battle of two powers is a battle for territory. To a greater extent, the two competing kingdoms were a reflection of the Christian Roman or Byzantine empire and the Zoroastrian or Magi-religious Persian Empire. In this battle, the ruler Himyar was defeated, and Yemen came to be in Abbisinia territory with its king Abrahah. During its development, Abrahah was interested in invading Mecca which was the center of paganism. Apart from that, Abrahah also built a Christian place of worship in the ancient city of Ma'rib under the name "Al-Qalis". One of the ways to build places of worship is to compete with the pagan practices of the people of Makkah, which are the center of the pilgrimage. If this effort is successful, it will yield benefits both economically and politically. But that never happened, because when Abrahah planned to destroy the Ka'bah in Makkah, his elephant army was attacked by a small virus. This incident is recorded by the Koran in the Surah Al-Fil [34]: 16 [18, pp. 78-79].

The destruction of Abrahah did not mean that Yemen was free from the rule of Abbisinian Christian rulers. The Jews and the inhabitants of Yemen hope that Christian power in Yemen will be lost. This hope was only realized in $575 \mathrm{AD}$ through the descendants of the ancient Himyar king Saif ibn Zi Yazan with the help of the Persian King Kisra Anusyirwan with compensation for paying taxes from the people of Yemen [18, pp. 83-84]. Although the people of Yemen were Jewish, they preferred to ask the Persian king for help because they were enemies of the Abbisinian Empire. Under Abbicinian rule, Judaism did not appear in the public sphere. However, the majority still have faith in Jews in the hearts of the population. This then made it easier for them to accept Islam when they sent friends of Mu'az bin Jabal, Ali bin Abi Talib and Abu Musa al-Asy'ari to the region [3, p. 25]. Yemen has the advantage because it is fought over by two major kingdoms. Apart from being rich in natural resources, Yemen is the gateway to dominating the Arabian peninsula [18, p. 82]. Despite jockeying for territory, the two great kingdoms while in power never placed their power in Yemen. As a result, Yemen was not under one king's power, but was split into social ties (kabilah) [22, pp. 84-86]. This then makes it easier for Islam to be accepted in Yemen.

\subsection{Religious Conversion of Ka'b Al-Ahbar}

The political conditions in Yemen, which are divided into social ties, are different from the Yasrib region, under Muhammad. Yemenis heard about the Prophet Muhammad's role in politics and the spread of a new religion that was theologically similar to Judaism from the Yemeni population living in Makkah and Medina. The trade caravans from Yemen then traveled to Medina [22, p. 99] to join Muhammad, both in religion and politics. In the year 8 $\mathrm{AH}$, especially after the conquest of Mecca, many Yemenis converted to Islam. This was marked by the migration of the Yemeni population to Medina, correspondence with Nab Muhammad and sending a delegation of friends to Yemen and the surrounding area [22, pp. 100-109], [23, pp. 75-77]. In welcoming the Yemeni people, Muhammad did not immediately invite him to accept Islam. Muhammad had known that the people of Yemen had known the concept of one god for hundreds of years. Apart from that, Yemen has also been established as a trading place in the Arabian Peninsula [22, p. 100].

Yemen, which was under the control of the Prophet Muhammad, began to have religious conversions. Previously Jewish residents of Yemen converted to Islam. However, whether Ka'b converted to Islam when the Prophet Muhammad was still alive or not, there are four opinions. Ka'b converted to Islam was recorded at the time of Prophet Muhammad, at the time 
of the Caliph Abu Bakr and at the time of Caliph Umar bin Khattab and at the time of the Caliph 'Ali bin Abi Talib [6, p. 151], [14, p. 68], [20, p. 29], [24, p. 397]. However, strong opinion states that Ka'b converted to Islam at the time of the Prophet Muhammad, but he never met him. The Jews, including Ka'b, converted to Islam because they felt that there was a similarity about one God [25, pp. 7-9]. In addition, from a political perspective, being under the Prophet Muhammad was more profitable than being under Persia.

Ka'b converted to Islam but never met the Prophet Muhammad. When the Yemeni delegation came to Medina, there was no name Ka'b in it. This can be understood because $\mathrm{Ka} \mathrm{b}$ is in a position of pure religion who lives in the social and political context of Yemen. $\mathrm{Ka}$ 'b converted to Islam in Yemen at the time of Prophet Muhammad in the presence of 'Ali ibn Abi Talib who was then sent to be a judge. This happened in $9 \mathrm{AH}$, or after the conquest of Mecca [20, p. 29], [23, p. 125], [26, p. 365]. However, there is also a lot of literature that mentions the conversion of Ka'b in the religion of Umar bin Khattab [14, p. 68]. This opinion is acceptable because the narrations relating to Umar's time are always connected with the story of Ka'b to Abbas regarding the factors that made him convert to Islam, namely because he discovered the characteristics of the Prophet Muhammad and his people in the Torah.

\subsection{The Encounter of Ka'b al-Ahbar with the Companions of the Prophet}

Islamic historical literature does not explain when Ka'b al-Ahbar met the companions of the Prophet Muhammad. However, when viewed from the Yemeni political context, the encounter of Ka'b with Muhammad's companions occurred when Mu'az bin Jabal and 'Ali bin Abi Talib were sent to Yemen. Islamic sources clearly record Ka'b's encounter with his companions, which began during the reign of Umar bin Khattab. During Umar's time, Ka'b came to Medina and stayed at the house of Umar's neighbor named Malik. To Malik, Ka'b asked how he could meet Umar. Malik replied, to meet Umar can be found after leading the prayer. Umar usually sat with many people and chatted with him [11, p. 202]. This encounter made Umar interested and believed in Ka'b. Later, Umar made him his political adviser in conquering the Syrian region and appointed him as the leader of the pilgrimage from Syria to Mecca and Medina [3, p. 31].

It is not clear why Umar bin Khattab was attracted to Ka'b al-Ahbar. Umar and his friends were attracted to Ka'b because of his extensive knowledge. Besides speaking fluent Jewish tradition, Ka'b was also able to fluently tell the Torah and the stories of the Children of Israel. However, Ka'b's efforts were considered to be only a clever strategy used to seek Muslim sympathy. The Ka'b were seen as Jews who converted to Islam in order to gain a good social class and saw the Jews as destroyers of Islam from the very beginning [27, pp. 216-218]. However, this opinion is not correct. Since the time of early Islam, Jews were often the "scapegoats" for all the chaos, even the wars that occurred during the early Islamic period. This kind of assumption is actually degrading friends like Umar bin Khattab, Usman, Ibn 'Abbas. These friends with big names were deceived by Ka'b. The acceptance of Ka'b was because he deserved respect because he had a lot of knowledge that the people of Medina did not have. Ka'b mastered the Jewish tradition and the stories of the past people are what attracts friends to get to know him more closely. In history, people who have the ability to tell stories about previous communities will have a high social class, that is, they are seen as scientists. Apart from storytellers, other names are fortune tellers (al-kahin) and poets. In Ka'b, there are two skills at the same time, namely storytelling and fortune-telling.

From this it can be understood if the friends respect Ka'b and make him a source of knowledge to ask all things, whether related to religious or political matters [28, pp. vii-ix]. 
Ka'b's knowledge came from his homeland which was the center of Jewish civilization. Ka'b who grew up as a Jew had memorized and understood the stories of the Israelites and other folk tales. Ka'b's status as a scholar or a religious Yemeni Jew also implied his nickname as a fortune teller [28, pp. 16-20]. One of the intellectual proofs of Ka'b al-Ahbar as a person who was sought after by the companions was when there was a history that informed him that Abu Hurairah was looking for Ka'b. Ka'b himself was delivering a lecture at the assembly. To Abu Hurairah, Ka'b asked: "What do you want from Ka'b?" Abu Hurairah replied: "I do not know any of the friends who memorized the traditions of the Prophet more than I did." Ka'b8 said: "Remember, you will not find a seeker for something unless one day he will be full of it, except for seekers of knowledge and seekers of the world." Then Abu Hurairah asked the man who was in front of him: "Are you the one named Ka'b?" Ka'b al-Ahbar replied: "Yes." Abu Hurairah said: "Because of this (seeking knowledge) I came to you." [10, p. 247]

The narration illustrates that Abu Hurairah was looking for Ka'b to study with him. Although Abu Hurairah was a friend of the Prophet Muhammad and narrated many hadiths, he still felt that he did not have enough knowledge. Therefore, he was looking for Ka'b, who since his arrival in Medina the news had spread to the ears of the companions. Abu Hurairah's encounter with Ka'b in a public space in Medina confirmed the opinion that he had met Umar when telling stories of the past. Apart from the story of Abu Hurairah, there is also a history of Ka'b with 'Aisyah. Before 'Aisyah, Ka'b said that the name Harun was mentioned in the QS. Maryam 28 is not as Aaron the brother of Moses. Then 'Aisyah denied it by saying: "O Ka'b, you are lying." To 'Aisyah, Ka'b explained: "O mother of believers, if the Prophet Muhammad had ever conveyed this, he would know better, but if he never said it then I actually found the time gap between Harun and Musa as much as 600. year." Then 'Aisyah is silent [11, p. 236]. From this dialogue, it is clear how Ka'b appeared in front of the companions and gave an explanation of the verse of the Koran which tells the names of the previous prophets.

The companions of the Prophet Muhammad from among young people admired Ka'b. Among the young friends there were names such as Abdullah bin 'Abbas, who was not yet 17 years old at that time. To Ibn 'Abbas, Ka'b gave the nickname of a smart person who manages the affairs of the people with knowledge (rabbani), or smart Jewish people [29, pp. 122, 6]. This nickname is only attributed to Ibn 'Abbas, because he inherited the knowledge possessed by Jewish intellectuals and their priests [3, pp. 59-60]. The nickname rabbani was later used by the friends and tabi'in to dub Ibn 'Abbas [10, p. 281]. Ka'b's encounter with the companions of the Prophet Muhammad did not only occur in the public sphere, but also in individual relationships. The names of friends who are full of familiarity with Ka'b are 'Usman bin' Affan and Mu'awiyah bin Abi Sofyan.

\subsection{Transformation of the Jewish Tradition into Islam}

Ka'b al-Ahbar always presents teachings or traditions that developed in Judaism in Islam. It is said that Ka'b saw a man take off his two sandals based on understanding QS. Taha [20]: 12 which contains Allah's command to Prophet Moses to take off his two sandals because they are in a holy valley. Ka'b said to the man, "Do you know the sandals worn by the Prophet Moses?" Then Ka'b explained that the sandals of Prophet Musa were made of dead donkey skin [30, pp. 535-536]. The story of taking off the two sandals comes from the Book of Exodus 3: 1-6 [3, p. 53]. However, not all sources of isra'iliyyat can be found in the books and traditions of the Jews in general, but some are from local Jewish traditions in Yemen. This is, for example, sourced from the narration containing the dialogue of Ka'b al-Ahbar with Abu Musa al-Asy'ari about the number and ranks of the inhabitants of heaven. Ka'b said, the 
inhabitants of heaven will line up into 12 lines, the ranks of the Prophet Muhammad's followers are 8. The distance from one line to the next is like the distance between East and West. This narrative is neither in the Torah nor the Talmud, but developed among the Yemeni Jews [3, p. 58].

It is said that when Abu Hurairah met Ka'b, Abu Hurairah sat down with him. Ka'b talked about the contents of the Torah, while Abu Hurairah delivered the sayings of the Prophet Muhammad about Good Friday. Ka'b commented that this particular Friday in one year only happens once. Then Abu Hurairah denied this, saying that Friday specialties occur every week. Then Ka'b read the Torah, after which he said: "The words of the Messenger of Allah are true". After meeting Ka'b, Abu Hurairah then met Abdullah bin Salam. To Ibn Salam, Abu Hurairah narrated Ka'b's initial opinion, then Ibn Salam blamed him. But when Abu Hurairah explained that Ka'b then read the Torah and confirmed the words of the Prophet Muhammad, Abdullah bin Salam also confirmed it [31, pp. 620-621].

Abu Hurairah's encounter with Ka'b al-Ahbar occurred after the two of them became friends, because Abdullah bin Salam, both in terms of age and conversion to Islam, was later than Ka'b al-Ahbar. The history describes how a Ka'b who had a Jewish tradition did not leave the Torah and other Jewish traditions in Islam. Ka'b was informed that he opened the Torah to check the truth of the words of the Prophet Muhammad, which to him was no stranger. Although he never met the Prophet Muhammad, the words of the Prophet Muhammad came from the Jewish tradition that developed in the Arab region, especially the South. Therefore, to confirm its truth it is illustrated by opening the Torah. Another example is when Ibn 'Abbas asked Ka'b about the meaning QS. An-Najm [53]: 13-16 which contains the story of the Prophet Muhammad seeing Jibril at Sidrah al-Muntaha. Ka'b explained, Sidrah al-Muntaha is a sidrah (tree or layer) at the end of 'arsy. In that place, all knowledge of beings, including the prophets and angels ends. Named Sidrah al-Muntaha, because knowledge ends with him [11, pp. 513-514]. Ka'b was also asked the meaning of ummu al-Kitab in the Koran [3, pp. 60-61].

The description above confirms that Ka'b is not only an agent of transformation of the Jewish tradition in the form of stories that are not explained in the Koran. Ka'b is also able to explain the verses of the Koran and relate them to the Torah. In almost all the surahs of the Koran, Ka'b gives commentary, although not all the verses in one chapter are related to previous religious traditions [32]. Meanwhile, the number of reports submitted by Ka'b could not be verified because many people made false reports which were based on him [33]. Although Ka'b was not a friend, he was a tabi'in, and not a few of the companions of the Prophet Muhammad did not hesitate to narrate from him, including Umar bin Khattab, 'Ali bin Abi Talib, Abu Hurairah, Mu'awiyah and Ibn' Abbas [34, p. 167]. The number of Companions of the Prophet Muhammad who asked about the meaning of the verses of the Koran to Ka'b clearly illustrates that Ka'b is a smart person. Arab societies tend to judge the stories of previous people as part of an interesting scholarship. The presence of Ka'b al-Ahbar who had the ability in that field made the Arab community sympathize with him. Apart from that, Ka'b also often held meetings attended by the Sabahat who told the stories of the past people. The meeting was held at the mosque and was permitted by Mu'awiyah, the leader of Syria [3, p. 48].

The nickname 'rabbani' which was given by Ka'b to Ibn 'Abbas because of his cleverness in telling stories about the prophets of the Israelites and previous peoples. The term is synonymous with smart Jewish people. Apart from some of these terms, the narrations from Ka'b also glorify Bait al-Maqdis, a place that was sanctified by the Jews. The stories that were conveyed by Ka'b in various forums were intended so that people who heard could take examples or examples from him. The habit of telling stories from previous people was 
prohibited at the time of the Prophet Muhammad because it was often used to hate and attack the Prophet and his companions. However, stories that do not contain hate speech are still preserved [28, pp. 27-28]. The stories of the ancient people were told through oral speakers and storytellers. Along with the codification of hadith, narrations were carried out by hadith scholars and Islamic historians.

From this it can be understood that Ka'b al-Ahbar in transforming the Jewish tradition into Islam acts as an agent of transformation or the foundation stone of the Jewish tradition into Islam. This was done through his encounter with the Companions of the Prophet both individually and collectively in an open meeting.

\section{Conclusion}

The transformation of the Jewish tradition into Islam through Ka'b al-Ahbar took place naturally. This is not as perceived by some scholars who claim to be an attempt to corrupt Islam from within (critics). The ability of Ka'b al-Ahbar to convey Jewish tradition led him to occupy the intellectual class as one of the authoritative Muslims. This is proven by the fact that many great friends asked Ka'b and invited him to tell stories to the Muslim public.

The encounter of Ka'b al-Ahbar with the companions of the Prophet Muhammad and the fondness of the Arab community in listening to the stories of the prophets of the Israelites and previous peoples became the main media for the transformation of the Jewish tradition into Islam. The very brief explanation of the Koran in informing the stories is also a factor that complements the opening of the great tap that flows the Jewish tradition into Islam.

\section{Refereces}

[1] M. H. Az-Zahabi, Al-Isra'iliyyat fi at-Tafsir wa al-Hadis. Kairo: Maktabah Wahbah.

[2] M. A. Al-Jabiri, At-Turas wa al-Hadasah. Beirut: Markaz Dirasat al-Wahdah al'Arabiyah, 1991.

[3] I. Wolfensohn, Ka'b Al-Ahbar. Jerusalem: Matba'ah Asy-Syarq at-Ta'awuniyyah, 1976.

[4] S. 'Abd al-Hasan, "Alfaz "Abariyah fi Kitab al-Huda ila Din al-Mustafa li al-Balaghi," Majallah Kull. al-Adab, vol. 91.

[5] R. Mustafa, "An-Nasyat al-Iqtisadi li al-Yahud bi al-Hijaz fi al-Jahiliyyah wa fi "Asr ar-Rasul Sallallahu 'alaihi wa Sallam,” Al-Jami'ah al-Islamiyah, vol. 2, 2004.

[6] I. 'Asakir, Tarikh Madinah Dimasyq. Beirut: Dar al-Fikr, 1997.

[7] I. Manzur, Lisan al-'Arab. Beirut: Dar Sadir, 1994.

[8] M. Az-Zabidi, Taj al-'Arus min Jawahir al-Qamus. tk.: Dar al-Hidayah.

[9] M. bin J. At-Tabari, Tarikh at-Tabari. Beirut: Dar at-Turas, 1967.

[10] A. 'Abdillah I. Sa'd, At-Tabaqat al-Kubra. Beirut: Dar al-Kutub al-'Ilmiyah, 1990.

[11] M. bin J. At-Tabari, Jami“" al-Bayan fi Ta wil al-Qur"an,. Beirut: Mu'assasah arRisalah, 2000.

[12] M. I. Hibban, As-Siqat. India: Wuzarah al-Ma'arif li al-Hukumah al-'Aliyah alHindiyah, 1973.

[13] I. bin M. Al-Asbihani, Siyar as-Salaf as-Salihin. Riyad: Dar ar-Rayah.

[14] A. Z. An-Nawawi, Tahzib al-Asma' wa al-Lughat. Beirut: Dar al-Kutub al-'Ilmiyah.

[15] J. As-Suyuti, Is 'af al-Mubta' bi Rijal al-Muwatta'. Mesir: Al-Maktabah at-Tijariyah al- 
Kubra, tt.

[16] I. Wolfensohn, Tarikh al-Yahud fi Bilad al-'Arab fi al-Jahiliyyah wa Sadr al-Islam. Mesir: Matba'ah al-I'timad, 1927.

[17] J. 'Ali, Al-Mufashshal fî Târîkh al- 'Arab Qabla al-Islâm. Baghdad: Jâmi’ah Baghdâd., 1993.

[18] P. K. Hitti, History of The Arabs. Terj. R. Cecep Lukman dan Dedi Slamet Riyadi. Jakarta: PT Serambi Ilmu Semesta, 2010.

[19] K. Anwar, Bintang Daud di Jazirah Arab. Semarang: ELSA Press, 2018.

[20] K. I. Ilyas, Ka'b al-Ahbar wa Asaruhu fi at-Tafsir. Beirut: Dar al-Kutub al-'Ilmiyah, 2007.

[21] I. Mouradgea, Muhadarat fi Tarikh al-Yaman wa al-Jazirah al-'Arabiyah Qabl alIslam, I. Beirut: Dar al-Hadasah, 1986.

[22] N. 'Abd al-L. Al-Hadis, Ahl al-Yaman fi Sadr al-Islam. Beirut: Al-Mu'assasah al'Arabiyyah li ad-Dirasat wa an-Nasyr.

[23] A. J. Al-Baghdadi, Al-Muhbir. Beirut: Dar al-Afaq al-Jadidah.

[24] S. Az-Zahabi, Tarikh al-Islam wa Wafiyat al-Masyahir wa al-A'lam. Maroko: Dar alGharb al-Islami, 2003.

[25] T. Noldeke, Tarikh al-Qur'an, I. Beirut: Konrad Adenauer Stiftung, 2004.

[26] A. B. I. A. Syaibah, Al-Kitab al-Musannaf fi al-Ahadis wa al-Asar. Riyad: Maktabah ar-Rusyd, 1989.

[27] J. A. Al-Misri, Asaru Ahl al-Kitab fi al-Fitan wa al-Hurub al-Ahliyyah fi al-Qarn alAwwal al-Hijriy. Madinah: Maktabah ad-Dar, 1989.

[28] W. M. Muhammad, "Daur al-Qassas fi Nasy'ati 'Ilmi at-Tarikh fi Sadr al-Islam," Jami'ah an-Najah al-Wataniyah Nablus Palestin, 2006.

[29] A. 'Abdillah Al-Qurtubi, Al-Jami" li Ahkam al-Qur"an. Kairo: Dar al-Kutub alMisriyyah, 1964.

[30] M. bin "Abd al-B. Az-Zarqani, Syarh az-Zarqani "ala Muwatta" al-Imam Malik. Kairo: Maktabah as-Saqafah ad-Diniyah, 2003.

[31] A. Q. 'Abdurrahman Al-Jauhariy, Musnad al-Muwatta'. Beirut: Dar al-Gharb, 1997.

[32] Y. M. Al-'Amiri, “'Ka'b Al-Ahbar: Marwiyyatuhu wa Aqwaluhu fi at-Tafsir bi alMa'sur,” Jami'ah Umm al-Qura Saudi Arabia, 1992.

[33] A. A. Twakkal, "Ka'b Al-Ahbar and the Isra'iliyyat in the Tafsir Literature," McGill University Quebec, 2007.

[34] S. bin M. As-Sakhawi, Fath al-Mughis bi Syarh Alfiyyah al-Hadis. Mesir: Maktabah as-Sunnah, 2003. 